\title{
J
}

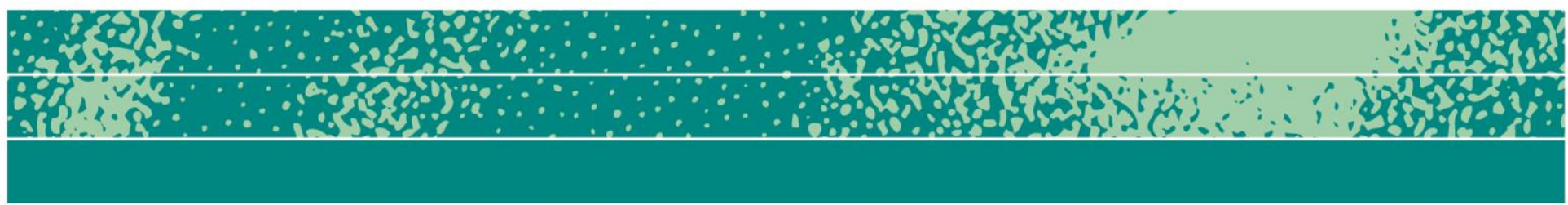

\section{Taxi drivers: ethnic segmentation, precarious work, and informal economic strategies in the Swedish taxi industry}

\author{
Zoran Slavnic
}

\begin{abstract}
This article invesitgates the processes of ethnic segmentation, precarious labour, and informalization in the Swedish taxi industry during a period of rapid deregulation during the 1990s. It does so by focussing on the life story of a single individual-Adem, a taxi driver in the Swedish city of Malmö. Despite his education, long working experience, and all efforts to make use of these advantages, all doors to an appropriate career in Sweden have remained closed to him. As a result, he has been pushed into working in the taxi sector, which is increasingly characterized by ethnic segmentation, hard working conditins, and harsh competition, forcing people to deploy informal economic strategies in order to survive. Adem's fate becomes strongly determined by these socio-economical processes. At the same time, the article shows that these processes are not separate, but are closely interrelated and reinforce each other. On the broader level these processes are a general consequence of the neoliberal reconstruction of Western economies, and structural economic, political and social changes related to it.
\end{abstract}

Page 1 of 22

JBA 4(2): 298-319

Fall 2015

(C) The Author(s) 2015 ISSN 2245-4217

www.cbs.dk/jba 


\section{Keywords}

Taxi industry, ethnic segmentation, informal economy, precarization, deregulation, Sweden.

\section{Introduction}

During my fieldwork in Malmö, I used a taxi more often than usual. I needed to meet several informants who lived or worked in different parts of the city. Taxis were the most efficient means of transport to get the job done. But perhaps the most important reason was the cost. An increasing number of taxi companies at the time charged only 45 kronor (US\$5.50) for all destinations within the city, which was actually a price my employers were prepared to pay. But this extremely low price was also something that I thought about every time while being driven. Three thoughts usually circulated in my mind.

First, this situation reminded me of Portes' story (1994:426) about the informalization of local transport in Miami. Local regular bus lines, employing union organized, mostly white, drivers were competing with the so-called jitneys, which were small and overcrowded, had no airconditioning, and were driven almost exclusively by immigrants. The service of the regular lines was indeed better: the buses were more comfortable, with air conditioners; but they were also more expensive, more infrequent, and stopped only at stations. The jitneys were cheaper, the service was more frequent and they used to stop wherever the customer wanted. Portes concluded that the competition between the controlled and irregular economy had never been as apparent as in this case. The same can therefore be said for the Malmö taxi situation. Cheap taxis are almost exclusively operated by immigrants, and they have multiplied so much that it is almost impossible to charge higher prices. The quality of service is perhaps somewhat lower-drivers may not have mastered the language and the cars are somewhat older and dirtier-but the client does not have to wait more than three minutes and the service is inexpensive. But, as we shall see later in this article, it is impossible for these firms to get bigger and better paid jobs, such as a contract with the bigger, luxurious hotels in the city, or fixed agreements with the municipality or county for transporting patients, the elderly and so on. Such contracts are almost exclusively reserved for larger and more established taxi companies.

Secondly, each time during the ride I tried to calculate how many fares taxi drivers have to take during the day to make it all worthwhile. Responding to my phone call, picking me up, taking me to the destination-an average ride can hardly be shorter than half an hour. This meant that they could not earn more than 100 kronor (US\$12) per hour. If they worked twelve hours a day, six days a week-about 26 working 
days a month-then the overall revenue per month might come to a maximum of 31,400 kronor (US\$3,750). Once they had paid for leasing the car, daily fuel, the dispatch centre service, plus car maintenance and washing, and payroll tax, what remained was far below the guaranteed lowest wages for employees in Sweden. And all this despite working a twelve-hour day, six days a week.

And finally, a third thing I started thinking about was the informal economy, or "black economy" (svart ekonomi), as this phenomenon is usually called in the political and media vocabulary in Sweden. When it comes to taxi fraud, according to the Swedish Taxi Association (Taxiförbundet 2014), more than 30 billion kronor in taxes have been lost since the taxi market was deregulated in 1990. These figures should, however, be taken with some caution. For instance, during the 1990s and early 2000s both authorities (SOU 2004-102; Skatteverket 2005) and media estimated that annual tax evasion came to four billion kronor in the taxi sector. The current estimate is one billion kronor (Taxiförbundet 2011). Despite the variations, there is a sort of general consensus that tax fraud is widespread within this sector, which is also often associated with other serious types of crime such as rape and robbery.

Through these short reflections I actually arrived at three keywords related to three socio-economic processes with which this article is going to deal. These are first the process of ethnification or ethnic segmentation of the taxi industry; secondly, the process of precarization, or progressive worsening of working conditions and reduction of (welfare) protection for employees; and thirdly the process of informalization within the sector: that is, increasing the volume of work done outside society's existing regulatory framework.

In other words, by using the life story of a single taxi driver in Malmö as an empirical base, the article aims to show how the radical worsening of working conditions within the sector was accompanied by two additional processes-ethnic segmentation and informalization-and how these three processes are not separate but closely interrelated and reinforce each other.

\section{Deregulation}

Deregulation of the Swedish taxi sector (implemented on 1 July, 1990) was in fact the beginning of an extensive deregulatory wave in Sweden during the 1990s, when a number of strictly regulated economic sectors (electricity, domestic air traffic, postal services, rail and taxi services and telecommunications) were opened to the "free market." Being considered a test case to prepare for later deregulations (Laitila et al. 1995:9), taxi deregulation was planned and organized very carefully. Among other things, all parts of the project were implemented on the same day (Marell \& Westin 2000, 2002). 
The main political argument behind deregulation was the low efficiency and high prices that had previously characterised the taxi market. Deregulation was expected to provide the necessary conditions for achieving a better balance between supply and demand, resulting in lower fares and a higher quality of service. Furthermore, competition was expected to improve efficiency, which in the longer run would decrease the number of smaller actors in the market, and at the same time increase the number of larger operators, who could than take advantage of economies of scale (NUTEK 1996).

However, in reality the market was liberalized: that is to say, formal measures of state regulations were removed, but better efficiency was not achieved. What really happened was a lowering of effectiveness in terms of the decreasing number of rides per vehicle and per working day and even time-productivity (the relationship between paid time and total working time) decreased (Laitila et.al. 1995). The resulting lower profitability forced people to work longer hours to earn the same wage. Simultaneously a new wage system for taxi drivers, a so-called "payment by result" (NUTEK 1996) was introduced, which meant that, especially within the larger taxi companies, the higher costs caused by the low effectiveness tended to be transferred to the employees, that is to say, the taxi drivers.

All this created conditions for the three inter-dependent processes with which this article is concerned: ethnic segmentation, precarious labour, and informalization. These matters will be discussed within the geographically limited area of Malmö/Lund, and through the life story of a single immigrant taxi driver.

The biographical method provides a useful tool for studying structure-agency dynamics, especially in the interdisciplinary studies of migration, ethnic business, and labour markets. When people choose to tell researchers their life stories it becomes possible to reconstruct those structural institutional and cultural patterns that constitute their biographies (Rosenthal 1993). A biographical-narrative interview that this article is based on was made as a part of my field work on ethnic business in Malmö, in the end of the first decade of 2000s.

\section{Ethnic segmentation}

Relying on the classic theory of a dual labour market (Reich, Gordon and Edwards 1973), Michael Piore (1979) argued in his concept of ethnic segmentation that international migration is caused in the first place by the demand for cheap and disposable labour in advanced capitalist economies rather than by social and economic processes in the countries that export labour. Secondly, he linked migration to the segmentation of labour markets. Indeed, immigrants most often become part of a secondary labour market, thereby providing more jobs and job security 
for the local population which mostly occupies the primary labour market.

There is a vast literature showing that Piore's segmentation theory is still relevant. It shows that changes in immigration policy towards tighter control are linked to the wider political and economic processes of the withdrawal of the welfare state, erosion of social rights, and labour re-commodification (Slavnic 2010; Munck et al. 2011). These policy changes have not prevented or even reduced immigration, but criminalized it instead (Jordan \& Düvell 2002; Anderson 2010), placing immigrants in a vulnerable, "precarious legal status" (Bernhard et al. 2007). The increased insecurity and legal uncertainty during the immigration process determines their position in the labor market even after they have resolved their legal status and become "full citizens" (Anderson 2010; Goldring \& Landolt 2011). Their precarious citizenship status continues to overshadow chances in the labor market (Munck et al. 2011), by providing opportunities to their employers to continue to exploit them (Jordan \& Düvell 2002; Wright \& McKay 2007). The life story that is the empirical foundation of this article is in many aspects quite illustrative of these processes.

Adem is 52 years old and a trained electrical engineer. He came to Sweden at the beginning of the 1990 s as a war refugee from Bosnia. ${ }^{1}$ In his homeland he had over many years built his career in a large company that competed internationally, operating within the same market as Sweden's ASSEA (today ABB). Once in Sweden, he applied for more than 200 jobs, but without success. He was not even called for a single interview. His disappointment was at its peak after an event that he describes as follows:

In the municipality of Arbåga there is an ABB factory producing high-voltage equipment. They announced a job vacancy for an electrical engineer. The ad matched so well to me and my qualifications that I myself could not have written a better prescription. It was exactly what I had previously dealt with, i.e. high voltage devices and their installation... And I applied immediately. I thought to myself that if I could get this job it would be brilliant. As I said, the job was as if it was tailored just for me. Besides, the ABB companies are very similar to Energoinvest. They were formerly ASSEA, which merged with a Swiss company that was named ABB. And coincidently it was ABB that I worked with during my time in Libya. For example, while we built a substation, ASSEA built an identical one, but with a different voltage level, about thirty yards from us. They

${ }^{1}$ Above mentioned tighter immigration control in Sweden relates just to refugees from the war in former Yugoslavia in the beginning of the 1990s (see Slavnic 2000). 
transformed for instance 220,000 to 110,000 volts, which we later took over, transformed it to 33000 volts before distributing it to the places where it was needed. And then a few days after I sent in my application, I received a letter in which they "thanked me for my interest." They had already hired someone else. Okay, I thought, there is nothing to do about it. Such things happen. Just three days later, however, I saw exactly the same ad in a newspaper. And then I wondered what this was all about. At that time I was in fact still unaware of Swedish discrimination, racism and so on. I thought instead that they might have needed a second engineer for the same post. So I phoned up the firm's personnel manager. I noticed immediately in his response that he tried to wriggle. Throughout the conversation it became increasingly clear that the ad was about the same job vacancy that I had already applied for. Finally, I asked a direct question: "Have you employed anyone following the previous ad?" He said, "No." "And you are now looking for an engineer for the same place?" His answer was, "Yes." I asked if it was worthwhile for me to once again submit an application for the post. The answer was, "No." I said, "OK, thank you" and hung up. ... This event hit me really hard.

We can only speculate about the reasons why the employer did not show interest in Adem, or even invite him for an interview, in spite of the fact that both his formal qualifications and his professional experiences were at least compatible and comparable with corresponding Swedish ones. It might have been his age, or assumed lack of language and cultural competence, or both. It might have been intended discrimination, based on ethnical stereotypes and prejudices, or what has been described by some scholars as statistical discrimination. It might have been a combination of all of these. Anyway, the result was blocked entrance to the primary labour market, which would have led to stable employment, good working conditions, relatively high wages, and chances of advancement.

In this respect, Adem's story is just another case supporting the findings on ethnic segmentation portrayed by academic literature in Sweden. Immigrants obviously encounter difficulties-both in the process of entering the labour market, and within it. When it comes to recruitment, despite their equal education, immigrants have a higher percentage of unemployment, are employed in unskilled occupations (Höglund 2002), or within atypical forms of employment compared with the Swedes (Jonsson \& Wallette 2001; Håkansson 2001). They are also more often excluded from the further recruitment process in the early stages (Hertzberg 2003; Neergaard \& Mulinari 2004). It is often sufficient to have a strange or unusual name to be excluded (Helgesson 2000). 
Furthermore, immigrants have significantly fewer chances to get jobs that are relevant to their qualifications than do Swedes (Martinsson 1998; Helgesson 2000). At the same time, such practices of exclusion lead to a systematic concentration of immigrants in simple industrial and service jobs, with a focus on physically demanding, stressful, or dirty jobs (Alund and Schierup 1991; Schierup et al. 2006; Slavnic 2012). Adem's story is quite illustrative of these processes. Soon after the incident mentioned above, he was persuaded by his friends to seek a new occupation, to become a taxi driver.

... A friend of mine said to me, "Adem, damn, why do you complicate things with all these applications? You have, of course, already noticed that it doesn't lead anybody anywhere. Instead, take a job as a taxi driver. Just look at me, I have already worked for five or six months. It is possible to cope with the job." So he tried to persuade me. And then he said that there were no problems with the job, the managers are mainly immigrants. There are also many Bosnians employed there who you can work with, which makes it all easier. Finally I decided to give it a try. My idea was that, during my employment as a taxi driver, I would continue to apply for the job I was meant for, electrical engineer. It's true, as my friend said. A few weeks later, after I attended a short training course in order to get my taxi license, I was employed as a taxi driver.

There are two things that we learn from this quotation. First, the more difficult it is to get a job in the primary labor market, the greater the push is to start working in the taxi sector, either as an employee, or as selfemployed. Secondly and related, it gives us some idea of how the process of ethnic segmentation works. Slavnic and Urban's (2008) geographical study covering the period 1990-2004 supports this trend by showing that the proportion of Swedish-born people working in the taxi industry had been constant during the period studied, while participation of the foreign-born population in the taxi sector has increased by around 20 per cent.

Adem's experience fits this trend well. In spite of higher education and many years of work experience, for him doors to employment in accordance with his qualifications and merits were obviously closed. At the same time, after deregulation, entrance-obstacles were removed, which enabled relatively easy access to jobs in the taxi industry. But at the same time, the sector was increasingly characterized by drastically worse working conditions, long workdays, and general uncertainty about the future. Testimony to this is offered by Adem's continued story. 


\section{Precarious work}

Adem's first employer was a man who had also come from former Yugoslavia, although thirty years earlier. Adem worked for him for about a year, six days a week, ten to twelve hours a day. Wednesdays were his days off. During the working shifts, time used to pass really quickly. There were more than enough calls and he almost never waited for one at the taxi depot. About a year later, however, his employer ran into financial difficulties. The tax authorities conducted an audit of his firm and decided he owed more than 100,000 kronor. ${ }^{2}$ He was forced to close down his business, and Adem found himself back at square one, facing the question: "What happens now?" At that time he still used to send job applications to companies in the engineering sector, but to no avail. The only solution he found reasonable at that point was to start his own taxi firm. He managed to get financial support from the state and credit from the bank to buy a new car. In order to be legitimate he also needed to complete some sort of taxi-specific education: luckily, a short course. Once it was completed, he was quickly able to start his business. The period he describes like this:

I worked as before, approximately ten to twelve hours per day, but working for myself I didn't even have Wednesdays off now. I worked every single day. My private affairs I performed on the road. For example, if I had to meet with the auditor, I waited until a time when I had to go to Malmö, where he was located. Before I went off I called him to see if he possibly had time to meet. The papers that would be needed during the meeting I had with me in the car. This was the way things were during the two years I was self-employed. The majority of taxi drivers work under the same conditions ...

The quote indicates that working conditions within the Swedish taxi sector increasingly deteriorated. There are several possible explanations for this. The first is an attempt to compensate for lower profitability by working longer days and nights-a frequent ploy in the taxi sector (Laitila et al. 1995). Unemployment statistics in Sweden since the early 1990s show significantly higher unemployment compared with the previous period. This means that a large number of individual actors were effectively forced to work in the sector despite deteriorating working conditions, by accepting longer hours and a lower income, because they had nowhere else to go. Another contributing factor in this context is that the taxi industry, as mentioned earlier, moved towards becoming ethnically segmented during the same period. To drive a taxi was for these people often the only form of paid work that was available.

\footnotetext{
2 Between 2006 and 2008 the Swedish tax authorities had conducted a so-called Taxi project, which resulted in additional taxation of about 280 million kronor, affecting about 2,000 companies and 1,400 drivers (Skatteverket 2009).
} 
These economic and social processes, however, are not particular to the taxi sector alone. If we remain focused on Sweden, we find similar trends (to keep the list short) in the household and cleaning sector (Gavanas 2010, 2013), the pizza trade (Hultman 2013), seasonal berry picking (Woolfson et al. 2012), and construction (Likic-Brboric et al. 2013). At the same time, the interconnection between migration, ethnic segmentation and precarization is related to wider global (neoliberal) changes (Hardt and Negri 2000; Harvey 2005; Anderson 2010). Precarization includes not only weaker basic socio-economic security (Standing 2005 2008), but allows for increased economic exploitation. To paraphrase Foti (2005), an increasing number of people who are exposed to precarization become "hireable on demand, available on call, exploitable at will, and fireable on a whim." Moreover, this kind of exploitation flows over into free time and disrupts "the continuum of everyday life" (Tsianos and Papadopoulos 2006).

The fact that Adem was self-employed does not make any difference. During the past three decades, the dominant political, media and academic discourses have glorified small firms and their owners as major creators of new jobs and growth. Self-employment is, however, often less glorious and represents the opposite of standard employment, because it provides weak socio-economic security and self-exploitation (Edgel 2005; Schierup et al. 2006). This is especially true when immigrants start their own small businesses (Slavnic 2004, 2013; Alund 2003; Abbsian 2003). Research shows that these kinds of owners find themselves in a much worse economic situation than immigrants who have regular employment (Hjerm 2001, 2004).

Regarding the taxi sector, Slavnic and Urban (2008) provide some empirical evidence for the growing income gap between Swedish-born and foreign-born taxi drivers. The foreign-born had an annual income that was only 80.3 per cent of the annual income of Swedish-born in 1991. This difference increased by 2004, when they earned only 68.6 per cent of the income of Swedish-born drivers. At the same time, the average disposable income in the taxi-sector (regardless of region of birth) has been lower than the average for all sectors in Sweden (ibid.:85). However, it was still more economically viable for foreign-born people to work in the taxi-sector than not to work at all. This explains, at least partly, their inclination keep working in the taxi-sector, despite increasingly worsening working conditions, and decreasing incomes.

At the same time, the only competitive strategy that many of these operators were able to deploy in order to remain in the market was to keep down charges. In Malmö all this started with so-called mini-taxis. I asked Adem how the phenomenon of the "mini-taxi" in Malmö began, and he said:

... It all started in 1994, I think. At that time they used those little Renault Clio cars. Almost all the first-established mini- 
taxi operators had them. The price for a ride was about 2830 kronor. When I started in this business, the price was only 35 kronor, then 39 , and finally around 45 kronor. What was it that made this profitable? Well, it meant that people began to travel more by taxi, it was simply cheaper. The business idea was thus to keep the car constantly running. Since the cars were not expensive, either in terms of pricing or service, they were also relatively durable.

Later this basic business idea got watered down. Suddenly larger cars showed up-first Opel Astra and then different kinds of mini-buses. Finally, the advantages of low costs were lost altogether. At the same time, prices remained low as more and more taxi operators began to operate in the same market. The majority of these new players competed, however, for private customers, because they had no chance to compete for business or government customers. Adem explains it like this:

... In this sector you are supposed to profile yourself according to the customer you want to attract. In Malmö/Lund, you have not more than two major taxi companies covering perhaps 90 per cent of all business customers. Taxi Skåne has over 300 cars. Taxi Kurir is another such firm. They are established all over the country, and over here they have as many cars as needed. If there is a need for as many as 100 cars, they will make sure to have that many on the spot. So there is no chance to compete with them... since they as a rule get all the big contracts... All mini-taxi companies are therefore compelled to find their way to retail customers, those who do not travel by taxi on a regular basis. There is a difference between private customers and business customers. The latter do not care-if for example the cost of the trip is 100 or 200 kronor, never mind. Comfort and punctuality are more important. If a private customer, on the other hand, needs to take a taxi from the pub to home, and pays out of his own pocket, then it pretty much matters if the price is 50 or 100 kronor, you know?

According to data from the Swedish taxi association (Taxiförbundet 1998), at the end of the 1990s 55 per cent of the total number of trips were so-called "publically funded," 21 per cent were business trips, and only about 24 per cent were private trips. The structure of the market has not changed significantly since that time (see Taxiförbundet 2014). At the same time, the total number of taxi companies in Sweden is approximately 8,000, operating 14,000 vehicles. Of these, some 6,000 were companies with only one vehicle and about 1,200 with just two vehicles. So more than 8,000 vehicles, that is 60 per cent of all taxi vehicles in Sweden, belong to these small firms. 
Here we need to consider who the main actors in Sweden's taxi industry are. First, there are the drivers (förare)-people employed in one of these 8,000 taxi companies. Even firms with only one car employ at least one extra driver, in order to improve a car's efficiency. Second are the private taxi companies, just described. The majority of these have only one or two cars, while the number of larger companies is actually very small. In 2008, there were 69 companies with 10-20 cars and only 41 companies with more than 20 cars (Taxiförbundet 2008). In fact, the largest taxi company in Sweden in 2008 owned not more than 150 cars (ibid.). Third, there are the dispatch centres. These normally do not have cars, but provide services to taxi companies that are registered under their logo. At the time of my research there were about 300 such dispatch centres, which included some 80 per cent of all taxi companies in the country (Skatteverket, 2009). Dispatch centres are usually registered as limited companies, and rarely as economic associations, where the owners of taxi companies are also the owners of the centre (although some of Sweden's largest dispatch centres-for example, Taxi Stockholm and Taxi Göteborg-are registered in this way). All companies registered in one dispatch centre have identical logos and telephone numbers on their cars, which then gives the impression that these dispatch centres (like Taxi Kurir) are large taxi companies owning all these smaller companies that operate under their logo. But in fact they are not, even if their power and influence of those are quite great, bearing in mind the fact that they may often include (and control) several thousand vehicles.

Companies that do not operate under the umbrella of a centre are the so-called free-wheelers (friakkare). The exact number of these is not known, but according to data cited in the introduction to this article (Bengtsson et al. 2000), in the late 1990s in Malmö about 40 per cent of all taxis were run by freewheelers. Since nobody had a monopoly in the local market, all companies had to compete for all market niches (ibid.). The preceding quote suggests, however, that freewheelers and smaller taxi centres were increasingly excluded from the business market. At the same time, it seems that competition in this market became additionally hard when large established taxi companies from other regions, such as Taxi Kurir, started establishing themselves in the Malmö region. This intensified competition led to further precarization of the taxi sector and increased the risk of raising the number of actors within this sector who were ready to employ informal economic methods in conducting their work. The next section will address these processes and strategies.

\section{Informal economic strategies}

The basic circumstances that forced Adem to run his business in the way he did consisted of blocked access to three-quarters of the market, on the one hand, and sharp competition for private customers, on the other. Coincidentally, his dispatch centre ran into trouble and the owners were 
forced to sell the business. Before I present and discuss the strategy deployed by the new owners in order to pull the company out of the crisis, it is necessary to explain the notion of "an informal economy."

An informal economy is traditionally understood as one operated primarily by marginal and disadvantaged social groups: in the first place, by unemployed poor and immigrants. This is not "the truth, the whole truth, and nothing but the truth" although it is certainly true that precarization is related to informalization. According to Tsianos and Papadopoulos (2006) the embodied experience of precarity is not only characterized by vulnerability (flexibility without protection), hyperactivity (constant availability), simultaneity (simultaneous dealing with multiple activities), and unsettledness (mobility through different space and time lines). It is also characterized by the need to become calculating, deceitful, and to cheat.

It is perhaps also true that members of disadvantaged social groups are over-represented in the informal economy, but they are certainly not those who make the biggest profit out of it. For example, Williams (2014) has shown that unemployed people in the UK earn only about one per cent of the total national earnings from informal work, while at the same time 97 per cent of total informal earnings is being taken by those with formal jobs. Participation in the informal economy in fact increases the marginalization of already marginalized social groups (ibid.:14).

In conceptualizing the economic system as either formal or informal-where the informal economy is a sort of an anomaly, preventing the formal economy from functioning normally- the unity of the economic system is overlooked (Leonard 1998; Williams 2014), and in turn this tends to over-emphasize the formal nature of our societies (Harding and Jenkins 1989).

Today there is a growing awareness, at least within the academic community, that the informal economy is not generated by marginal social groups nor by increased immigration. Indeed, it is not an anomaly, but an integral part of the formal economy (Sassen 1998; Likic-Brboric et al. 2013; Standing 2011). Informalization is related to the capitalist mode of production. It is in general the result of a structural conflict between old (welfare) modes of regulation and new (neoliberal) regimes of accumulation. Essentially, the old regulatory frameworks have become too tight for new forms of capital accumulation to be able to expand without disruption. Consequently, all economic actors are more likely to try to achieve their economic aims outside existing regulatory frameworks, in other words, by using informal economic strategies (Slavnic 2010).

The informal economic strategies deployed by powerful social actors, such as big businesses and state institutions, have been identified as "informalization from above." At the same time there are informal 
strategies developed partly as survival strategies, and partly as resistance to informalization from above, by small and less powerful actors (small business owners and marginalized immigrant entrepreneurs), which have been called "informalization from below"(ibid.).

If we return to the Swedish taxi-sector, the dominant political and media discourses define the informal economy as the property of those marginal social groups, who are viewed as a major part of that economy (Slavnic 2011). At the same time, the media make a clear distinction between so-called seriös ${ }^{3}$ taxi companies (and dispatch centres) and companies that are prone to illegal activities. This tendency to criminalize small taxi companies and freewheelers is extensively used by large companies as part of their business strategy, in order to run the small operators out of the market. They usually present themselves (and most media and political actors accept this new discourse as the truth) as $a$ priori decent economic actors who have in fact been most severely harmed by irregularities within the taxi sector. Their actual motives, however, are not a desire for justice and order, but rather their strong interest in out-competing their competitors and thereby capturing monopolistic positions in the market (ibid.). This kind of strategy is nothing other than "informalization from above."4

Smaller companies (and dispatch centres) in turn seek to get rid of being labeled as oseriös, ${ }^{5}$ partly by (over)investing in external features that they perceived characterize a seriös company. They understand that this is characterized by significantly higher prices and better service, which is often reflected in the fact that drivers have uniforms. But, as Adem's story shows, it is not always enough just to have the intention to become a seriös taxi firm. He describes how the new owners, making an effort to pull the dispatch centre out of its crisis, actually pushed it even further into the mire.

They tried to bring order into the company. ...The first change they introduced was to raise prices. Then they raised the price for being connected to their dispatch centre. They also introduced a rule on uniforms, inspired by Taxi Skåne. To me the uniform issue was less important, but they thought it was the most important change and it was almost only this issue that used to be discussed during our regular monthly meetings. Has the driver worn a tie, was the tie neat and tidy, and so on. At the same time, the real problems were growing. One was that we certainly lost up to 60 per cent of all the customers we had ever had.

\footnotetext{
${ }^{3}$ Swedish idiom, meaning serious, describing decent, law-obiding companies;

${ }^{4}$ For more detailed discussion of the concept "informalization from above" see Slavnic, 2010 and Slavnic, forthcomoing 2016;

5 Swedish idiom, meaning un-serious, describing, fraudulent, deceitful companies;
} 
Why? Simply because this clientele was made up of retirees and students, meaning people with tight finances. Prior to the changes, our low prices at about 39 kronor per ride, with the longer journeys being slightly more expensive, were acceptable. The price would only be slightly more expensive than travelling by bus, and so of course they would call a taxi. Even pensioners thought the prices were affordable. With higher prices, however, one could see clearly how this customer base started disappearing.

This and similar situations led to a number of cases of illegitimate competition, even among colleagues from the same dispatch centre. Adem describes a few such cases:

What was the result of this? Well, when enough work is no longer available for all, some drivers manage to retain part of their daily income, while others earn less and less money. Who are those who keep their incomes? Well, they are those who cheat, who steal others' customers, they are such people.

$Z S$ : What do you mean by stealing customers?

Adem: Yes, they simply steal customers. In this business, there are many thieves. We all had a rule about how strong the radio transmitters in the cars could be, but some drivers tuned theirs to a very strong broadcasting signal, so strong that only their signal was visible on the taxi centre's computer screen. Or another such typical case was when the taxi centre sent me to take a run from Gunnesbo, while another driver was there in the vicinity. For me it would perhaps take about 6-7 minutes to get to the site, while for him it would only take half a minute. Under our current rules the cars that are in motion do not have the right to take these trips, only the cars waiting at the centre. But it often happened that they did pick up customers anyway, as in my case. And then a few minutes later I showed up over there like a fool.

$Z S$ : But you never know who's picked up your client?

Adem: You can find out if you have time to do it, but it is not always easy-especially if the customer was already waiting for a taxi when he shows up. He picks up the customer directly and disappears.

This was an obvious example of unfair and cruel competition, based on informal strategies which are part of the struggle for survival among most marginalized groups and individuals in the labour market and are part of informalization from below. They were used as a last resort in the struggle for survival, in a situation where all other opportunities to 
survive in the "formal" economy were closed. A similar conclusion from their study of the informal strategies of taxi drivers in a small English town, Moonhaven, is drawn by Jordan and Travers (1998). They write that these are rational economic actions performed in response to structural constraints that arise as a consequence of changes that occur within the so-called formal economy. At the same time, since this strategy is actually the only way to survive, it cannot be seen as immoral by those who carry it out. Moralizing in this context could be perceived as hypocrisy, and not as legitimate criticism (ibid.: 298).

In any case, when it comes to Adem, he eventually decided to close down his company. When I asked him about the real causes behind this decision, he answered:

The key reasons were several. The first was the poor profitability in the third year, which was the result of the bad business policy and working conditions in the taxi association. And the second reason was that I really got tired. I got tired of both exhausting work and working conditions, but also of the taxi profession as such. It's incredibly tough to drive taxis for a long time, especially mini-taxis... In my case it worked out that during one run I'd get a second booking, and then during the second run, I'd book a third, and that was the way it was going all day. You had to constantly keep in mind all these things, and I was constantly under stress. Taxi business really kills one, wears out one...

This quotation in a way sums up the message that Adam wanted to give me, but also summarizes academic points that this article wishes to communicate. The gospel of flexibilization, as Standing (2011:24) puts it, tells people that they have to obey market forces and always be available and endlessly adaptable. Adem tells us nevertheless that nobody can do it indefinitely. In other words, there is a fundamental contradiction between neoliberal (unlimited) demand for flexibility and human beings limited capability to fulfill this demand. Unless they employ informal economic strategies that in this case become a rational response to structural downward pressure towards greater flexibility, which these individuals are not able to resist. The other alternative, which Adem chose, was to give up.

My last question to Adem was what he thought about the current situation in the taxi industry in general and in particular about the situation in Malmö/Lund:

Listen, what happens in this industry is not a coincidence...

There are many people, especially down here in southern Sweden, who cannot find a job... Almost all are highly educated ... but they could not obtain employment commensurate with their level of competence and were 
therefore forced to take up employment in the taxi industry. For society, it was some sort of safety valve. It was better that these people took employment as taxi drivers than to stroll through the employment agencies, or in the streets or even end up in newspapers articles about crime or abuse. The state is looking through its fingers; all sorts of problematic business strategies within the sector are tolerated to keep these people in some sort of employment.

This brings us to the role of the state in this context. Adem is quite confident-even categorical-in his assessment of the situation, asserting that the state tolerates informal economic strategies in the taxi sector, as a sort of "labour market policy measure." Moreover, he is not the only one who thinks so. Several of my informants, involved in or related to the taxi industry, have given me similar assessments.

During the past fifteen years, for instance, several commissions have been appointed by the Government ${ }^{6}$ or different state agencies/departments ${ }^{7}$ charged with investigating irregularities in the taxi sector. But, despite these investigations clearly pointing out the problems within the taxi industry as well as proposals for how to deal with them, the Government has actually done nothing concrete.

An example of this is the proposal for special de-tanking centres (or reporting centres for taxis, as they are called in most recent documents), where the data from all taximeters were to be registered and saved. The proposal was first presented in 1997, but in SOU 1999:60 it was officially offered as a strategy for dealing with tax evasion in the taxi sector.

This particular story has been going on for the past seventeen years, covering two mandates of social democratic government and additionally two mandates of centre-right coalition government. Throughout this period basically all relevant actors-media, various state agencies (among others the Competition Board and the National Tax Agency), trade unions and branch associations-repeatedly pressed the state to implement effective legislation in order to do something about these problems. Politicians have nevertheless ignored all these claims.

Eventually, after continuous political demand, underpinned by a

\footnotetext{
${ }^{6}$ SOU 1997:111, Branschsanneringsutredningen; SOU 1999:60, Taxiutredning "Kundvänligare taxi"; SOU 2004:102 Ekonomisk brottslighet inom taxibranschen; SOU 2010:76 Transportstyrelsens databaser på vägtrafikområdet-integritet och effektivitet.

${ }^{7}$ Redovisningscentraler för taxi-Ds 2013:66, Departementsserien (Ds) 5 november 2013; Näringsdepartementet; Skatteverket (2008); Skattefelskarta för Sverige, (2008:1); Skatteverket (2014) Skattefelets utveckling i Sverige 20072012. Note that these two reports, made by the Swedish tax agency, deal with tax evasion in all economic sectors, including the taxi sector.
} 
number of reports issued by various organisations, agencies and institutions, on 25 July, 2012 the government appointed yet another commission to investigate the possibility of establishing reporting centres for taxis. The findings were presented in February 2013 and led to a new Law on reporting centres. The parliamentary decision was made on 10 July, 2014, and the Law should come into force on 1 January, 2016.

This looks like the end of this story. From 2016, the state is expected to collect at least one billion kronor more each year in income tax, and taxi customers may expect to have better and safer services. But there are rumours within the taxi sector about the newest technical solutions making it possible both to order the nearest taxi cab and to pay for the service via a smart phone app (Taxiförbundet 2014b). Certain groups within the sector are said to believe that this new technology makes taxi meters useless and unnecessary. This seems to confirm the view that the state is purposefully ignoring the problems within the taxi sector. The Law on reporting centres has been approved only now, when it is practically impossible for it to be implemented.

But this article has actually presented the opposite example (Taxi project 2006-2008), showing how tax authorities deployed decisive measures in order to clean up the taxi sector. Therefore, the only safe conclusion may be that state policy in this context has been quite ambivalent, inconsistent, and sometimes contradictory. In fact, there is nothing peculiar in this, because the story of the Swedish taxi sector's deregulation is, in this way, also a story about the neoliberal reconstruction of the Swedish welfare state. Such large structural changes are always accompanied by internal conflicts between old and new ideologies, old and new moralities, old and new policies. In the course of time new (neoliberal) ideology, morality and policies have become dominant, creating a new social order (Dumenil and Levi 2002) in which Adem's life story is embedded.

\section{Concluding discussion}

This article has dealt with the socio-economic consequences of the rapid deregulation of the Swedish taxi-sector during the 1990s through the experience of a single immigrant taxi driver, as these effects were manifested in the geographical region of Malmö-Lund. As we have seen, the fate of Adem is strongly determined by structural changes in the economy and new (neoliberal) economic trends.

Although highly educated and with long working experience behind him, all doors to an appropriate career in Sweden remain closed to Adem. At the same time, thanks to deregulation and the removal of most entry barriers, it was relatively easy for him to establish a taxi business. This sector, however, became increasingly run by "pure" market forces, characterized by harsh competition, extreme deterioration of working 
conditions, and growing uncertainty. Consequently, the sector became less attractive for all those who were able to find a job in any more lucrative industry, while at the same time it has also become the last refuge for the most vulnerable individuals and groups in society, who do not have that chance.

On a broader level, the present processes of growing ethnic segmentation and precarization are intimately related to the rise of neoliberal capitalism, for which migration serves as an important vehicle by making the labour markets more flexible and reducing the cost of labour (Munck et al. 2011, 254-255; see also Schierup \& Alund 2014). Mass migration still appears to be a necessary condition for capital accumulation (Hardt \& Negri 2000; Bauder 2006). Or, to put it more accurately, it is not immigration and immigrants as such that contribute to capital accumulation, but their precarious position in the labour market, which makes them attractive to a capitalist economy. "[T]hey are valuable just because they are vulnerable" (Bauder 2006:22). By being systematically pushed into the secondary sectors of the labour market, migrants help stabilize it for non-migrants (ibid.:23). At the same time, and in the long run, they also help the neoliberal reconstruction of the labour market, which means worse working conditions and poorer work protection for all (Standing 2011).

This article also questions a common taken-for-granted "truth" about the informal economy: its causes and carriers. Normally informalization is regarded as a salient feature for marginalized and disadvantaged social groups. In sharp contrast to these views, this article offers an alternative explanation: informalization in Western economies is a general consequence of the deep economic, political and social changes that characterize such societies, generally described as "postFordist transformation." Informalization is a result of a structural conflict between new, neoliberal economic trends and old (welfare) regulatory frameworks. However, the resulting processes of welfare state retrenchment, economic deregulation, labour market, and labour flexibilization and re-commodification, do not affect all private and public economic sectors, or all individuals and social groups, equally. Some of them become more exposed to these processes, some less. What actually happens is that grey zones within national economies are being constituted-grey zones which are especially exposed to precarization and informalization and in which economic actors cannot survive without employing informal economic strategies. As these zones grow, they tend to absorb the most exposed individuals and social groups - in Sweden's case the immigrants. 


\section{References}

Abbasian, S. 2003 Integration på egen hand: en studie av invandrade kvinnoföretagare i Sverige, Kulturgeografiska institutionen. Uppsala universitet, Uppsala.

Anderson, B. 2010 "Migration, immigration controls and the fashioning of precarious workers." Work Employment and Society 24 (2): 300-317.

Andersson, P. 2006 Four Essays on Self-Employment. Department of Economics, University of Stockholm, Stockholm.

Bauder, H. 2006 Labor Movement: How Migration Regulates Labor Markets. Oxford: Oxford University Press.

Bengtsson, M., Gälstedt, M. and Marell, A. 2000 “Co-operation and market segmentation: Non-political barriers replacing political barriers post deregulation." Paper read at 3th KFB Research Conference, Stockholm, June 13-14.

Bernhard, J. K., et al. 2007 "Living with precarious legal status in Canada: Implications for the well-being of children and families." Refuge: Canada's Journal on Refugees 24 (2): 101-114.

Duménil, G. and Lévy, D. 2002 "The nature and contradictions of neoliberalism." Socialist Register 38: 43-72.

Edgell, S. 2005 The Sociology of Work: Continuity and Change in Paid and Unpaid Work. London: Sage.

Gavanas, A. 2010 Who Cleans the Welfare State? Migration,

Informalization, Social Exclusion and Domestic Services in Stockholm.

Stockholm: Institute for Futures Studies.

Gavanas, A. 2013 "Migrant domestic workers, social network strategies and informal markets for domestic services in Sweden." Women's Studies International Forum 36: 54-64.

Goldring, L. and P. L. 2011 "Caught in the work-citizenship matrix: the lasting effects of precarious legal status on work for Toronto immigrants." Globalizations 8 (3): 325-341.

Hardt, M. and Negri A. 2000 Empire. Cambridge, MA and London: Harvard University Press.

Harvey, D. 2005 A Brief History of Neoliberalism. Oxford: Oxford University Press.

Helgesson, L. 2000 Högutbildad men diskvalificerad - Några invandrares röster om den svenska arbetsmarknaden och vägen dit. Gerum Kulturgeografi, Umeå universitet, Umeå.

Hertzberg, F. 2003 Gräsrotsbyråkrati och normativ svenskhet: hur arbetsförmedlare förstår en etniskt segregerade arbetsmarknad. Arbetslivsinstitutet, Stockholm.

Hultman, H. 2013 Liv och arbete i pizzabranschen. Lund: Arkiv Förlag.

Håkansson, K. 2001 Språngbräda eller segmentering? En longitudinell studie av tidsbegränsat anställda. Institutet för arbetsmarknadspolitisk utvärdering, Forskningsrapport, Stockholm. 
Höglund, S. 2002 Kunskapsöversikt över svensk forskning om rekrytering, kvalifikationsvärdering och kompetenshantering 1990-2001, med inriktning mot forskning som kan belysa eventuell diskriminering. ThemES, Occasional Papers and Reprints on Ethnic Studies, SEUS, Department of Ethnic Studies, Linköpings Universitet, Norrköping.

Jonsson, A. and Wallette, M. 2001 "Är utländska medborgare segmenterade mot atypiska arbeten?" Arbetsmarknad \& Arbetsliv 7 (3): 153-168.

Jordan, B. and Duvell F. 2002 Irregular Migration: The Dilemmas of Transnational Mobility. Cheltenham: Edward Elgar Publishing Ltd.

Jordan, B. and Travers, A. 1998 "The informal economy: a case study in unrestrained competition." Social Policy \& Administration 32 (3): 292-306.

Laitila, T., Marell, A. and Westin, K. 1995 Taxitrafikens egenskaper och taxikundernas uppfattning fyra år efter avreglering. KFB -

Kommunikations Forsknings Beredningen, Stockholm.

Leonard, M. 1998 Invisible Work, Invisible Workers: The Informal Economy in Europe and the US. London: Macmillan.

Likic-Brboric, B., Slavnic, Z. and Woolfson, C. 2013 "Labour migration and informalisation: East meets West." International Journal of Sociology and Social Policy 33 (11/12): 677-692.

Marell, A., and Westin, K. 2000 "The taxi deregulation-outcome in rural areas." 3th KFB Research Conference, June 13-14, Stockholm.

Marell, A., and Westin, K. 2002 "The effects of taxicab deregulation in rural areas of Sweden." Journal of Transport Geography 10: 135-144.

Martinsson, H. 1998 Högutbildade invandrares inkomster åren 1985 och 1990. Umeå, Kulturgeografiska institutionen, Umeå universitet. Munck, R., et al. 2011 "Migration, work, and citizenship in the new world order." Globalizations 8 (3): 249-260.

Neergaard, A, and Mulinari, D. 2004 Den nya svenska arbetarklassen. Umeå: Borea.

NUTEK 1996, Avregleringen av taximarknaden. En analys av regionala effekter. NUTEK Rapport, Stockholm.

Näringsdepartement 2013 Redovisningscentraler för taxi.

Departementsserien (Ds) 5 November 2013, Stockholm.

Piore, M. J. 1979 Birds of Passage: Migrant Labor and Industrial Societies. Cambridge: Cambridge University Press.

Portes, A. 1994 “The informal economy and its paradoxes." In Swedberg, R. and Smelser, N.J. (eds.), The Handbook of Economic Sociology, Princeton and NY: Princeton University Press \& Russell Sage Foundation, pp. 426449.

Reich, M., Gordon, D.M. and Edwards, C.M. 1973 "A theory of labor market segmentation," American Economic Review 63 (2): 359-365. Rosenthal, G. 1993 "Reconstruction of life stories. Principles of selection in generating stories for narrative biographical interviews." The Narrative Study of Lives 1 (1): 59-91. 
Sassen, S. 1998 Globalization and Its Discontents: Essays on the New Mobility of People and Money. New York: The New Press.

Schierup, C-U, Hansen, P. and Castles, S. 2006 Migration, Citizenship and the European Welfare State. Oxford: Oxford University Press.

Skatteverket 2005 Svarta inkomster står för större delen av skattefusket, Pressmeddelande 2005-10-13, Stockholm.

Skatteverket 2008 Skattefelskarta för Sverige. Stockholm.

Skatteverket 2009 Taxiprojektet 2006-2008: Slutrapport. Stockholm

Skatteverket 2014 Skattefelets utveckling i Sverige 2007-2012. Stockholm.

Slavnic, Z. 2000 Existens och temporalitet: Om det samtida flyktingskapets komplexitet. Sociologiska institutionen. Umeå: Umeå universitet.

Slavnic, Z. 2004 Immigrants and Small Business Research in Sweden-An Overview, ThemES, Centre for Ethnic and Urban Studies, University of Linköping, Norrköping.

Slavnic, Z. 2010 "Political economy of informalisation." European Societies 12 (1): 3-25.

Slavnic, Z. 2011 "Struggle for survival in the deregulated market: Recommodification and Informalisation of the taxi sector in Stockholm." Forum for Social Economics 40 (2): 233-251.

Slavnic, Z. 2012 "Breaking out-barriers against effort, biographical work against opportunity structures." Journal of Business Administration Research 1 (2): 1-17.

Slavnic Z. 2013 "Immigrant Small Business in Sweden: A Critical Review of the Development of a Research Field." Journal of Business Administration Research 2 (1): 29-42.

Slavnic, Z. forthcoming 2016 "The informal economy and neoliberal state." In Routh, S. and Borghi, V. (eds.) Workers and the Global Informal Economy: Interdisciplinary Perspectives. London and New York: Routledge.

Slavnic, Z. and Urban, S. 2008 "Socio-economic trends in the Swedish taxi sector: deregulation, recommodification, ethnification." International Journal on Multicultural Societies (IJMS) 10 (1): 76-94.

SOU 1997:111, Branschsaneringsutredningen, Stockholm.

SOU 1999:60, Kundvänligare taxi, Stockholm

SOU 2004:102, Ekonomisk brottslighet inom taxibranschen, Stockholm.

SOU 2010:76, Transportstyrelsens databaser på vägtrafikområdet integritet och effektivitet, Stockholm.

Standing, G. 2005 "Why basic income is needed for a right to work." Rutgers Journal of Law \& Urban Policy 2 (1): 91-103.

Standing, G. 2008 "Labour recommodification in the global transformation: How to achieve economic security." Social Indicators Research 81 (1): 15-30.

Standing, G. 2011 The Precariat: The New Dangerous Class. London: Bloomsbury Academic. 
Svenska Taxiförbundet 1998 Detta är svensk taxinäring och Svenska Taxiförbundet, pressinformation, 1998-05-27, Stockholm.

Svenska Taxiförbundet 2011 Branschleget 2011. Stockholm: Svenska Taxiförbundet.

Svenska Taxiförbundet 2014 Branschläget 2014, Stockholm: Svenska Taxiförbundet

Tsianos, V. and Papadopoulos D. 2006 "Precarity: A savage journey to the heart of embodied capitalism." Transversal-EIPCP Multilingual Web Journal 11 http://eipcp.net/transversal/1106/tsianospapadopoulos/en, (Access date 10.10.2015).

Williams, C. C. 2014 "The informal economy and poverty: evidence and policy review." http://works.bepress.com/colin_williams/34 From the Selected Works of Colin C Williams.

Wright, T. and McKay S. 2007 Undocumented Worker Transitions: United Kingdom Country Report. EU Sixth Framework Programme: Contract Number: 044272.

Woolfson, C., et al. 2012 "Forced labour and migrant berry pickers in Sweden." International Journal of Comparative Labour Law and Industrial Relations 28 (2): 147-176.

Ålund, A. and Schierup, C.-U. 1991 Paradoxes of Multiculturalism. Aldershot: Avebury.

Ålund, A. 2003 “Self-employment of non-privileged groups as integration strategy: Ethnic entrepreneurs and other migrants in the wake of globalization." International Review of Sociology 13 (1): 77-87.

Zoran Slavnic is a sociologist and researcher in the field of work, migration and citizenship at the REMESO (Institute for Research on Migration, Ethnicity and Society), Linköping University (Sweden). His research concerns informalization, re-commodification of labour, migration, the Swedish taxi sector and working conditions, opportunity structures and welfare of immigrant entrepreneurs (see http://www.isv.liu.se/medarbetare-vid-isv/slavnic-zoran?l=en). His broader academic interests also include methodology and sociological theory. He may be reached at zoran.slavnic@liu.se. 